\title{
Pembelajaran Bahasa Indonesia Menggunakan Komik Digital pada Siswa Tingkat SMA/MA.
}

\author{
Ririn Oktavia* \\ E-mail: ririn.oktavia2470@student.unri.ac.id \\ *Program Studi Pendidikan Bahasa dan Sastra Indonesia, Universitas Riau
}

\section{Pendahuluan}

Pembelajaran adalah dasar proses interaksi peserta didik dengan pendidik dan sumber belajar pada suatu lingkungan belajar. Pembelajaran merupakan bantuan yang diberikan pendidik agar terjadi proses perolehan ilmu dan pengetahuan, penguasaan kemahiran dan tabiat, serta pembentukan sikap dan kepercayaan pada peserta didik.

Pembelajaran adalah seperangkat peristiwa-peristiwa eksternal yang dirancang untuk mendukung beberapa proses belajar yang bersifat internal. Pembelajaran dimaksudkan untuk menghasilkan belajar, situasi eksternal harus dirancang sedemikian rupa untuk mengaktifkan, mendukung, dan mempertahankan proses internal yang terdapat dalam setiap peristiwa belajar Gagne (1977).

Konsep pembelajaran kurikulum 2013 yaitu pembelajaran merupakan suatu proses pengembangan potensi dan pembangunan karakter siswa sebagai hasil dari sinergi antara pendidikan yang berlangsung di sekolah, keluarga dan masyarakat. Pembelajaran kurikulum 2013 ditujukan untuk mengembangkan potensi peserta didik agar memiliki kemampuan hidup sebagai pribadi dan warga negara yang beriman, produktif, kreatif, inovatif, dan kehidupan masyarakat, berbangsa, bernegara, dan berperdaban dunia.

Kemudian perkembangan dunia kini tengah memasuki era evolusi manusia. Menyiapkan lulusan yang berkualitas dan mampu bersaing secara global, dan menguasai perkembangan teknologi merupakan hal yang penting untuk semua orang dan penting bagi masa depan suatu negara (Kanematsu \& Barry, 2016). Dengan demikian, dukungan dan peran pendidikan diharapkan 
dapat meningkatkan daya saing bangsa di tengah persaingan global pesatnya perkembangan teknologi informasi.

Untuk mewujudkan peserta didik yang memiliki kemampuan hidup sebagai pribadi dan warga negara yang beriman, produktif, kreatif, inovatif, dan mengerti teknologi perlu adanya dukungan belajar yang baik sevara fisik maupun non fisik. Selain dukungan, peserta didik juga perlu adanya sarana alternatif untuk meningkatkan semangat belajar dan meewujudkan keberhasilan dalam proses belajar mengajar. Pada penulisan ini penulis memberikan alternatif yang mengandalkan kekreatifan pada peserta didik melalui digital pada saat ini. Tujuan dari pembelajaran komik digital ini agar peserta didik tidak bosan dengan isi materi yang hanya penuh dengan tulisan saja dan tujuannya agar peserta didik bisa memanfaatkan teknologi secara kreatif. Pembelajarn ini hanya untuk peserta didik teingkat SMA/MA.

\section{Hakikat Komik Digital}

Pembelajaran dengan media komik digital yaitu dengan menyajikan gambar-gambar dengan menggunakan deretan alur cerita yang berisikan materi pembelajaran Bahasa Indonesia. Gambar-gambar yang disajikan tentu saja tidak terlepas dari kaidah komik. Cerita akan muncul dari pengertian berdasarkan gambar komik yang dilihat siswa sehingga siswa mampu mendapat ide dan mengolah atau mengembangkan kreatifitas.

Media pembelajaran komik menurut Trimo (1997:22) menyatakan bahwa

: 1. Komik menambah pembendaharaan kata-kata pembacanya;

2. Mempermudah peserta didik mengankap hal-hal atau rumusan yang abstrak;

3. Dapat mengembangkan minat baca peserta didik dan salat satu bidam studi yang lainnya;

4. Seluruh jalan cerita pada komik menuju satu hal yakni kebaikan atau studi yang lain.

Dengan pembelajaran menggunakan komik digital siswa dapat menjadikannya sebagai cara merangsang dan menarik untuk mempraktikkan kemampuan bahasa dan peserta didik dapat dengan mudah mengingat materi pembelajaran. 


\section{Sarana Pendukung}

Sarana pendukung menjadi unsur terpenting dalam perwujudan instrument pembelajaran agar instrument mampu digunakan dengan maksimal pada proses pembelajaran. Berikut merupakan sarana pendukung dalam pelaksanaan pembelajaran dengan komik digital :

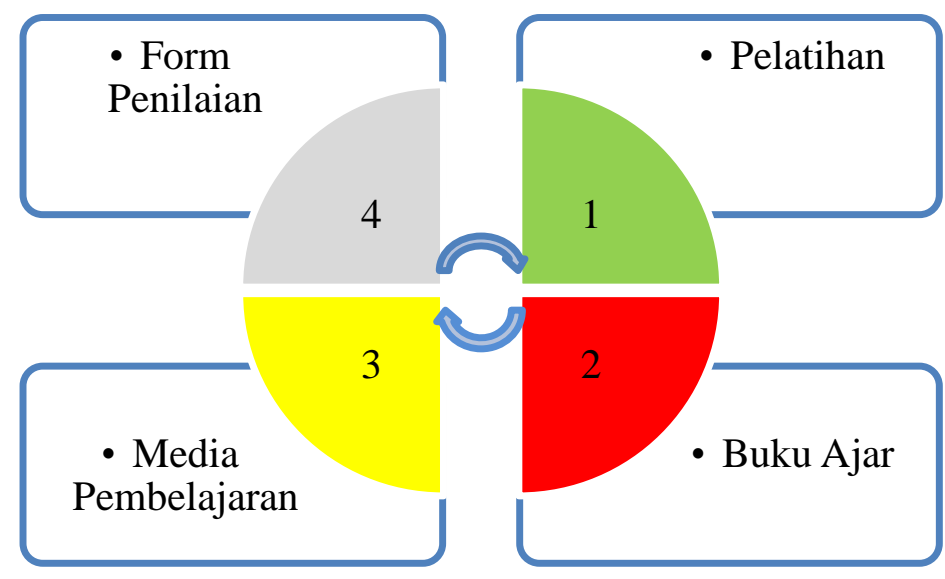

Gambar 1. Sarana Pendukung

1. Pelatihan, Pelatihan disini ditujukan untuk guru mata pelajaran bahasa Indonesia. Guru mata pelajaran disarankan mengikuti pelatihan terlebih dahulu sebelum menerapkan pembelajaran kepada murid. Pelatihan ini bertujuan agar tidak keliru saat mempraktikkan kepada siswa.

2. Buku ajar, selain pelatihan guru juga harus memiliki buku ajar. Melalui buku ajar akan meminimalisir kesalahan dalam penyampaian materi oleh guru terkait pembelajaran Bahasa Indonesia.

3. Media pembelajaran, siswa harus memiliki media pembelajaran atau sekolah harus menyediakan media pembelajaran agar siswa bisa mengikuti pembelajaran dengan lancar. Adapun media pembelajarannya berupa teknologi digital seperti laptop.

4. Form Penilaian, dengan form penilaian guru dapat melihat perkembangan dan tingkat ketercapaian siswa dalam pembelajaran. 
Langkah-Langkah Implementasi Pembelajaran Menggunakan Komik Digital

Implementasi pembelajaran menggunakan komik digital tahap pelaksanaan sebagai berikut:

1. Guru membagi siswa menjadi beberapa kelompok dengan tujuan agar siswa bias berkerja sama dan menimbulkan rasa sosialisme antar siswa.

2. Selanjutnya, guru memberikan materi yang akan siswa jadikan komik. Materi yang dibagikan untuk setiap kelompok berbeda-beda.

3. Kemudian, guru menjelaskan sekilas tentang materi yang akan dijadikan komik. Dan guru menjelaskan bagaimana cara membuat serta menggunakan aplikasi yang telah disediakan untuk membuat komik tersebut.

4. Setelah itu guru memberikan kesempatan kepada siswa yang ingin bertanya atau kepada siswa yang kirang mengerti tentang cara membuat komik.

5. Setelah waktu tanya jawab selesai, guru memberikan waktu selama 2 minggu untuk progres pengerjaan komik tersebut.

6. Kemudian setiap minggunya tugas guru ialah mengecek dan membim bing siswa dalam berdiskusi.

7. Setelah waktu berdiskusi selesai, setiap kelompok diharuskan membagikan komik digital tersebut ke semua kelompok yang ada atau bisa disebutkan barter materi.

8. Kemudian setiap kelompok diharuskan untuk menjelaskan materi yang ada dikomik tersebut dengan rinci, sehingga pembaca komik tidak bingun dan materi yang disampaikan jelas serta terarah.

9. Setelah semua kelompok mempresentasikan hasil komik digital mereka, pembelajaran diakhiri dengan mengisi kuis yang telah disediakan oleh guru.

10. Kemudian guru dapat menilai sejauh mana pemahaman murid menggunakan metode pembelajaran dengan komik digital. 
Pembelajaran dengan media komik digital adalah penyusunan gambar dengan urutan-urutan tertentu, yang didalamnya mencakup tokoh yang memiliki karakter dalam sebuah rangkaian cerita dengan tujuan memberikan unsur hiburan dalam penyampaian materi pembelajaran dan dengan tujuan mencari inovatif baru dalam pembelajaran Bahasa Indonesia.

Metode pembelajaran menggunakan komik digital dapat meningkatkan kefektivitas pembelajaran pada mata pelajaran Bahasa Indonesia. Siswa menjadi lebih semangat dalam belajar dikarenakan disamping membaca siswa juga dapat melihat gambar tokoh kartun yang ada dikomik.

Metode ini juga bertujuan agar siswa paham dan bisa memanfaatkan teknologi digital. Serta agar siswa lebih aktif dan kreatif dalam membuat cerita maupun mendesain gambar sesuai dengan keinginan siswa. Dan juga melatih kekompakkan antar sesama siswa.

\section{REFERENSI}

Abdul Wahab. (2016). Wasis dan Sifak Indana. Pengembangan Bahan Ajar Komik pada Materi Sistematis Transportasi Makhluk Hidup Untuk Menumbuhkan Minat Baca Dan Meningkatkan Hasil Belajar. Jurnal ISSN Vol. 6, No 1 Pendidikan Sains Pascasarjana Universitas Surabaya.

Trimo. 1997. Media Pendidikan. Jakarta: Depdikbud

Hake, Richars R. 1998. “Interactive Engagement VersusTraditional Methods: Asixthunsand-student Survey of Mechanics Test Data For Introductory Physics Course”. Am. J. Phys. 66 (1), January, 1998.

http://referensi.data.kemendikbud.go.id

McCloud, Scoot. 2001. Memahami Komik. Jakarta: Kepustakaan Populer Grameddia. 
Riwanto,dkk (2018). Aktivitas Penggunaan Media Komik Digital (Cartoon Story Maker) dalam Pembelajaran Tema Selalu Berhemat Energi. Jurnal PANCAR Vol. 2, NO. 1.

Mustafa, M. N., Hermandra, \& Zulhafizh. (2019). Teachers' Strategies to Design Media to Implement Communicative Leaning in Public Schools. Journal of Educational Sciences, 3(1), 13-24.

Roosje Kawuwung, Femmy. 2019. Implementasi Perangkat Pembelajaran Inkuiri Terbuka. Malang: Seribu Bintang.

Trimo. 1997. Media Pendidikan. Jakarta: Depdikbud

Trianto. 2010. Model Pembelajaran Terpadu. Jakarta: Bumi Aksara.

Tahyatul Izza, (2013). "Pengembangan Media Pembelajaran Komik Digital Bahasa Indonesia Untuk Meningkatkan Kemampuan Menulis Cerita Pendek (Cerpen) Kela IX Semester Ganjil Di SMP Negeri 4”. Bandung:Alfabeta. 


\section{*Data Penulis}

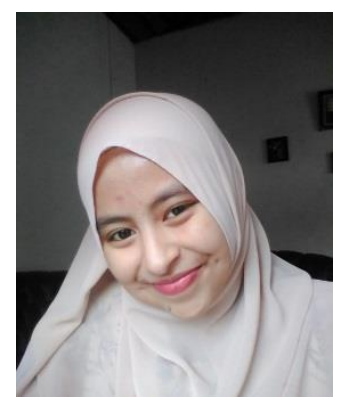

Ririn Oktavia, lahir di Pekanbaru, 31 Oktober 2000. Pada tahun akademik 2020 - 2021, Ia melanjutkan studi pada strata satu Jurusan Pendidikan Bahasa dan Seni di Program Studi Pendidikan Bahasa dan Sastra Indonesia FKIP Universitas Riau melalui jalur SBMPTN, sekarang masih berstatus mahasiswa. Sederet prestasi yang selama menjadi mahasiswa yakni peserta lomba tulis esai bulan bahasa 2020, peserta lomba tulis cerpen praktikum sastra ke-29 se-Indonesia dan peserta lomba tulis essai bulan bahasa 2021. Ia juga merupakan seorang penari.

\section{Kontak:}

Instagram :_rrinokt

Facebook : Ririn Oktavia

Email : ririn.oktavia2470@student.unri.ac.id 